\title{
Supporting science teaching practice with learning progressions
}

\author{
Professor Erin Furtak \\ University of Colorado, Boulder \\ https://doi.org/10.37517/978-1-74286-638-3_14
}

Erin Marie Furtak, PhD, is Professor of STEM Education and Associate Dean of Faculty at the University of Colorado, Boulder. A former high school science teacher, Erin transitioned into a career studying how science teachers learn and improve their daily classroom practices through formative assessment. In a series of multiple studies, Erin has been partnering with teachers, schools and districts to learn how teachers can design, enact and take instructional action on the basis of classroom assessments that they design. Her recent publications have examined the ways in which the design and enactment of classroom assessments can promote more equitable participation in science learning.

\section{Abstract}

Learning progressions are often used as foundations for curriculum and assessment. At the same time, as representations of the development of student ideas and practices, they can also serve as maps to support teachers during instruction. This paper describes a program of research in which my colleagues and I have investigated how learning progressions can support high school science teachers in cycles of co-designing formative assessments.

\section{Introduction}

For decades, science education has emphasised students engaging in the thinking processes of scientists as they learn the big ideas in science. These reforms have been reflected in frameworks for science learning internationally, such as the Next Generation Science Standards in the US (National Research Council [NRC], 2012) and in the framework for the International Program for Student Assessment (Organisation for Economic Co-operation and Development [OECD], 2017). These ambitious visions for science learning raise expectations for the ways in which teachers design and facilitate learning environments that reposition student thinking at the centre of classroom activity and place high demands on teachers to enact. To realise this new vision of science education, teachers will need to participate in long-term, ongoing professional learning that provides them with tools and frameworks to navigate student thinking in three-dimensional learning experiences (National Academies of Sciences, Engineering, and Medicine, 2015).

In this paper, I describe an ongoing program of research in which I have partnered with teachers, administrators, district leaders and other researchers to co-design learning progressions as representations of the ways student ideas and engagement in science practices develop over time, and have used these progressions to support teachers' collaborative design of formative assessment tasks. Conducted primarily in high school, this research has explored the ways in which a routine for professional learning, which we have called the Formative Assessment Design Cycle, can scaffold the ways teachers navigate student thinking with the support of learning progressions. 


\section{Learning progressions}

I work from the definition of learning progressions as hypotheses for how student ideas can develop over time, from the lower-anchor, everyday ideas they have when they come to school, to the topanchor, scientifically accepted understandings they reach after participating in school (Alonzo \& Gotwals, 2012). The middle levels chart out various pathways for how these ideas can develop over time. I then take these representations as orienting frameworks for systems of assessment (Shepard et al., 2018); that is, the progressions themselves can help to inform the design of learning sequences, as well as assessment tasks.

We have explored how learning progressions can also be direct supports for teachers as they learn to navigate students' thinking in reform-oriented science teaching, all toward the outcome of broadening participation in science learning. From this perspective, teacher learning, curriculum and assessment design, and students' learning can all be coordinated around and by learning progressions that represent the ideas and practices students are expected to learn within a span of time.

\section{Formative assessment}

Formative assessment is a fundamental element of science teaching and learning reforms (NRC, 2014). By creating opportunities for students and teachers to surface and discuss ideas while instruction is in progress (e.g. Black \& Wiliam, 1998), formative assessment is an ideal activity to help teachers connect students' ideas and experiences with science, and to adapt and adjust learning experiences to better centre students' interests and needs. The phrase 'formative assessment' itself can refer to both the tasks that teachers use to organise classroom activity, as well as the practices in which students and teachers participate around these tasks, as well as informally in the course of listening and responding to student ideas (Bennett, 2011). Formative assessment tasks are designed to consist of multiple components that create space for students to share their thinking, through open-ended questions, drawing models, writing explanations and other features (Fine \& Furtak, 2020; Kang et al., 2014; NRC, 2014). Formative assessment practices are the actions teachers and students engage in to ask each other questions, to push each other's thinking and to better understand each other's ideas (e.g. Cowie et al., 2011). While formative assessment remains a key mechanism for teachers to support student learning, it remains a challenging practice for both pre- and in-service science teachers.

\section{Routines for formative assessment task design: The Formative Assessment Design Cycle}

To support teachers' abilities to enact formative assessment, my research team has developed a routine for teachers' collaborative co-design of formative assessment tasks centred on learning progressions. The Formative Assessment Design Cycle (Furtak et al., 2014; Furtak \& Heredia, 2014) consists of five steps, summarised in Figure 1. First, teachers explore students' thinking with the support of a learning progression, and then they design formative assessment tasks to embed in units of instruction. Next, they practice using those tasks, anticipating how to elicit and respond to student ideas related to the learning progression before enacting the tasks with students. Finally, teachers gather to reflect upon enactment, using the learning progression to interpret artifacts of student thinking and to plan next steps for instruction. 
Figure 1 Formative Assessment Design Cycle

\begin{tabular}{|c|c|}
\hline & $\begin{array}{l}\text {-Explore students' thinking, including discussions of teachers' prior experience with student } \\
\text { ideas in a given disciplinary area }\end{array}$ \\
\hline & $\begin{array}{l}\text {-Adapt existing assessment tasks or develop new tasks that create space for students to } \\
\text { share their thinking/engagement in practice }\end{array}$ \\
\hline & $\begin{array}{l}\text {-Discuss participation structures for enacting task with students, including different levels } \\
\text { of groupings; plan how task will organise routines around sharing \& responding to student } \\
\text { thinking }\end{array}$ \\
\hline & $\begin{array}{l}\text {-Use task in classroom with students; collect samples of student work (written responses, } \\
\text { posters, pictures of whiteboards or posters, etc.) }\end{array}$ \\
\hline & $\begin{array}{l}\text {-Interpret student ideas and plan next steps for instruction based on enactment of task; } \\
\text { where applicable, note revisions for task for subsequent academic years }\end{array}$ \\
\hline
\end{tabular}

Along with members of my research team and our school district partners, I have used these routines to organise regular meetings of science teacher professional learning communities. As shown in Figure 2, these meetings can be spread out, with an intensive focus on one instructional unit within a school year. Alternatively, meetings can happen more frequently across a nine-month school year, with teachers completing multiple cycles of exploring student ideas, designing and practising using tasks, enacting, and reflecting together.

Figure 2 Frequency of meetings within an academic year

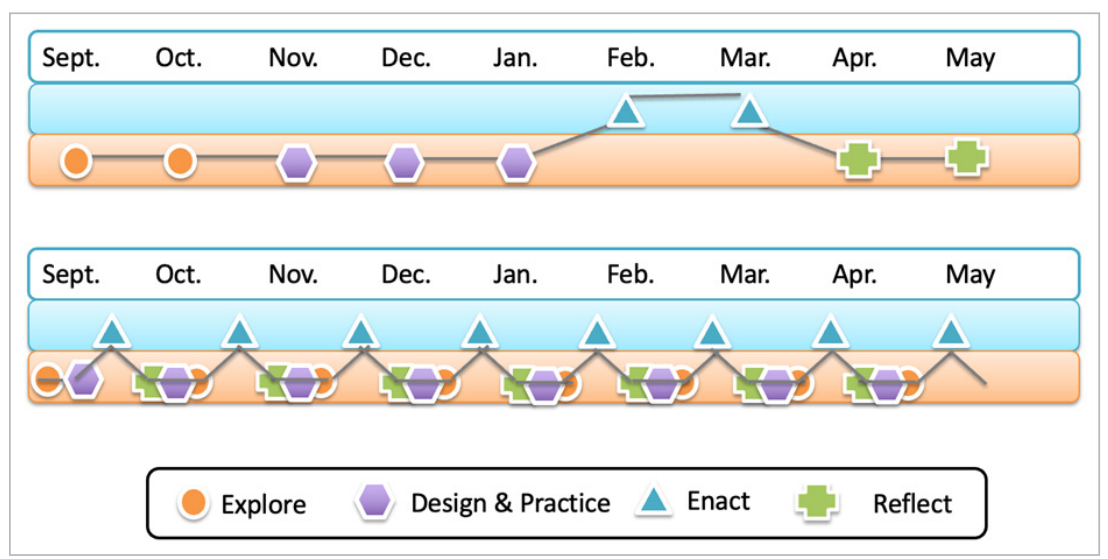

\section{Case example: A learning progression to support vertical alignment in high school science}

My team has collaborated with teachers and curriculum leaders in a large culturally, ethnically, linguistically and socioeconomically diverse school district. This collaboration has taken the form of a research-practice partnership (Penuel et al., 2011), in which researchers and practitioners develop mutually beneficial goals to support shifts in classroom practice while also producing knowledge for the broader science education community. The intention of the second study was to examine the ways in which a learning progression could provide opportunities for vertical alignment across high school science courses. 
District science leaders were interested in how science teachers could have interdisciplinary conversations about student learning by exploring crosscutting concepts, or concepts and ideas that span across science disciplines (e.g. Nordine \& Lee, 2021). One of the crosscutting concepts in the Next Generation Science Standards is energy and matter flows, cycles and conservation (NRC, 2012). We developed a new learning progression on the basis of prior progressions created for energy in physics (Neumann et al., 2013) as well as studies of energy as a crosscutting concept (e.g. Park \& Liu, 2016). In addition, we integrated the science practice of modelling (Pierson et al., 2017; Schwarz et al., 2009) to create a hypothesised trajectory for how students model energy transfers and transformations across systems (Buell et al., 2019; see Figure 3).

Figure 3 Learning progression for modelling energy

\begin{tabular}{|l|l|}
\hline Level & A learning progression for modelling energy flows \\
\hline 5 & $\begin{array}{l}\text { - Students are able to generalise their model to unknown or multiple phenomena, and can explain } \\
\text { limitations of applying the model to a new phenomenon. }\end{array}$ \\
\hline 4 & $\begin{array}{l}\text { - Students develop a model that illustrates a mechanism that can explain or predict the } \\
\text { phenomenon AND use the model to make predictions about how changing one part of the } \\
\text { model would influence energy flows elsewhere in the system. }\end{array}$ \\
\hline 3 & $\begin{array}{l}\text { Students can explain how the energy of the system constrains the magnitude of change } \\
\text { - Students can describe limitations of the model in explaining or predicting the phenomenon. }\end{array}$ \\
\hline $\begin{array}{l}\text { - Students use or develop a model that relates changes in the phenomenon directly to changes in } \\
\text { dissipation. } \\
\text { - Model includes energy flows into, within and out of the system. } \\
\text { - Students use or develop a model to illustrate a relationship or pattern between the increase in } \\
\text { one form of energy and the decrease in another form, or transferred from one location or object } \\
\text { to another. } \\
\text { - Students identify the most relevant component and relationships in the model and distinguish } \\
\text { between the system and surroundings. } \\
\text { - Model focuses on energy flows within the system only. }\end{array}$ \\
\hline 1 & $\begin{array}{l}\text { Students use or develop a model that shows, through drawings or labels, the components } \\
\text { involved in a phenomenon, some (but not necessarily all relevant) energy forms, transfers or } \\
\text { transformations. }\end{array}$ \\
\hline 1
\end{tabular}

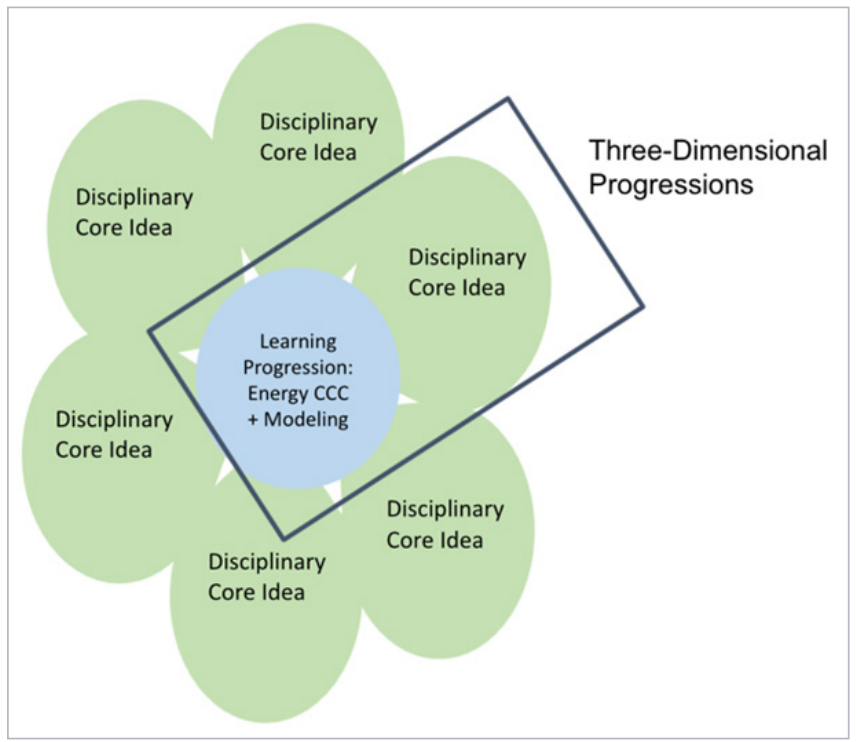


Our intention was that a learning progression focused on an idea that cut across physics, chemistry and biology. It could also create space for students to create models of energy transfers and transformations in different real-life scenarios and opportunities for teachers to support student learning of energy more systematically across grade levels.

We started out by engaging teachers in exploring their own understandings of energy by asking them to model energy transfers and transformations in a simple calorimetry lab. This lab involved teachers creating a simple, inefficient calorimeter and burning a puffed cheese snack, and then drawing models in cross-disciplinary groups. They noticed right away that the language they used to describe energy was different based upon their own content preparation; for example, in chemistry, teachers would talk about thermal energy in exo- and endo-thermic reactions, whereas biology teachers would teach about energy within ecosystems.

On the basis of these shared learning experiences, teachers then moved into discipline-specific groups and used the common learning progression to plan classroom assessment tasks and learning experiences for their own science courses. Teachers developed an array of different formative assessment task types, as shown in Figure 4, to support students' modelling of energy (Buell, 2020). In-depth analyses of teachers' conversations in content-specific teams found that the routines of the formative assessment design cycle facilitated deeper conversations about student thinking across multiple years of the study and supported teachers in designing better assessment tasks to surface student thinking (Henson, 2019). In addition, the tasks facilitated teachers making key connections between students' everyday experiences with energy - such as around exercise and respiration - although this varied across classrooms. 
Figure 4 Sample assessment tasks for modelling energy

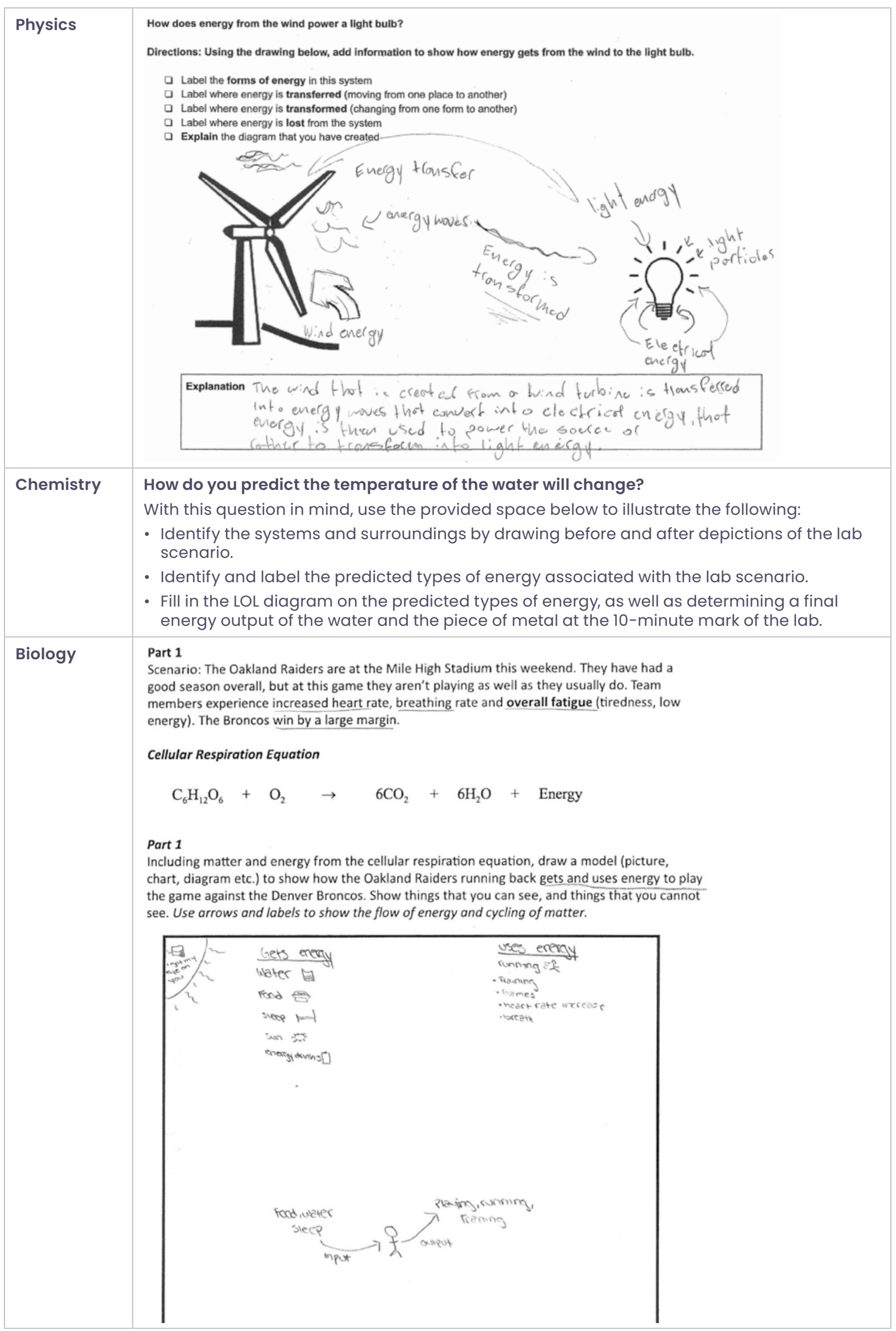




\section{Take-aways for learning progressions and teacher professional development}

As this short case example illustrates, there are multiple opportunities for teachers to collaborate with the support of learning progressions focused on the big ideas and practices of science. While formats for learning progressions vary widely, and their availability is not consistent across science domains, using available learning progressions and adapting them in collaboration with teachers can nevertheless support key conversations about students' opportunities to learn, and to create space to talk together about designing better assessment tasks over time.

This material is based upon work supported, in part, by the National Science Foundation under Grant No. 1561751.

\section{References}

Alonzo, A. C., \& Gotwals, A. (2012). Learning Progressions in Science: Current challenges and future directions. Sense Publishers.

Black, P., \& Wiliam, D. (1998). Assessment and classroom learning. Assessment in Education: Principles, Policy \& Practice, 5(1), 7-74. http://dx.doi.org/10.1080/0969595980050102

Bennett, R. E. (2011). Formative assessment: a critical review. Assessment in Education: Principles, Policy \& Practice, 18(1), 5-25. https://doi.org/10.1080/0969594X.2010.513678

Buell, J. Y. (2020). Designing for relational science practices. [Doctoral dissertation]. University of Colorado Boulder.

Buell, J. Y., Briggs, D. C., Burkhardt, A., Chattergoon, R., Fine, C., Furtak, E. M., Henson, K., Mahr, B., \& Tayne, K. (2019). A learning progression for modeling energy flows in systems. Center for Assessment, Design, Research and Evaluation (CADRE).

Cowie, B., Jones, A., \& Otrel-Cass, K. (2011). Re-engaging students in science: Issues of assessment, funds of knowledge and sites for learning. International Journal of Science and Mathematics Education, 9(2), 347-366. https://doi.org/10.1007/s10763-010-9229-0

Fine, C., \& Furtak, E. M. (2020). A framework for science classroom assessment task design for emergent bilingual learners. Science Education, 104(3), 393-420. https://doi.org/10.1002/ sce. 21565

Furtak, E. M., \& Heredia, S. C. (2014). Exploring the influence of learning progressions in two teacher communities. Journal of Research in Science Teaching, 51(8), 982-1020. https://doi.org/10.1002/ tea. 21156

Furtak, E. M., Morrison, D., \& Kroog, H. (2014). Investigating the link between learning progressions and classroom assessment. Science Education, 98(4), 640-673.

Henson, K. (2019). Designing tools to support teacher activity focused on student thinking to inform instruction. [Doctoral dissertation]. University of Colorado Boulder.

Kang, H., Thompson, J., \& Windschitl, M. (2014). Creating opportunities for students to show what they know: The role of scaffolding in assessment tasks. Science Education, 98(4), 674-704. https://doi.org/10.1002/sce.21123 
National Academies of Sciences, Engineering, and Medicine. (2015). Science Teachers' Learning: Enhancing opportunities, creating supportive contexts. The National Academies Press.

National Research Council. (2012). A framework for K-12 science education. National Academies Press.

National Research Council. (2014). Designing assessments for the Next Generation Science Standards. National Academies Press.

Neumann, K., Viering, T., Boone, W. J., \& Fischer, H. E. (2013). Towards a learning progression of energy. Journal of Research in Science Teaching, 50(2), 162-188.

Nordine, J. \& Lee, O. (2021). Crosscutting concepts: Strengthening science and engineering learning. NSTA Press.

Organisation for Economic Co-operation and Development. (2017). PISA 2015 Assessment and analytical framework: Science, reading, mathematic, financial literacy and collaborative problem solving, revised edition. PISA, OECD Publishing.

Park, M., \& Liu, X. (2016). Assessing understanding of the energy concept in different science disciplines. Science Education, 100(3), 483-516.

Penuel, W. R., Fishman, B. J., Cheng, B., \& Sabelli, N. (2011). Organizing research and development at the intersection of learning, implementation, and design. Educational Researcher, 40(7), 331-337. https://doi.org/10.3102/0013189X11421826

Pierson, A. E., Clark, D. B., \& Sherard, M. K. (2017). Learning progressions in context: Tensions and insights from a semester-long middle school modeling curriculum. Science Education, 101(6), 1061-1088.

Schwarz, C. V., Reiser, B. J., Davis, E. A., Kenyon, L., Achér, A., Fortus, D., Shwartz, Y., Hug, B., \& Krajcik, J. (2009). Developing a learning progression for scientific modeling: Making scientific modeling accessible and meaningful for learners. Journal of Research in Science Teaching, 46(6), 632-654.

Shepard, L. A., Penuel, W. R., \& Pellegrino, J. W. (2018). Using learning and motivation theories to coherently link formative assessment, grading practices, and large-scale assessment. Educational Measurement: Issues and Practice, 37(1), 21-34. https://doi.org/10.1111/emip.12189 